\title{
4.2 有機錫安定剂の赤外吸収
}

市眅の各種有機錫安定剂つ赤外吸収は図12〜16のようになった．同じ名称であってもまったくことな った吸収があらわれることが多い。乙れは合成中に反応調整のために稀釈用の有機溶剂を用いたてと， 合成後に各種添加剂を加えたてと，各種原因によって分子式通りの棈造になってないてと，などのため

表10 ジブチル錫系安定剂の $1700 \mathrm{~cm}^{-1}$ 附近の吸收の波数

\begin{tabular}{llll}
\hline ジラウレート & 1730 強 & 1705 強 & \\
マレエート & 1773 弱 & 1740 \\
& & 1717 強 & $0.03 \mathrm{~mm}$ \\
& & 1725 強 & サンドイッチ \\
\hline
\end{tabular}

であろう。たとえば dibutyl 錫 dilaurate は Cdの laurate と同じ位置に band progression があらわれてよいのであるが，実際はあまりはっ きりしていない.

$1700 \mathrm{~cm}^{-1}$ 附近には表10のような吸収がみとめ られた。他の例から推測するとやはりカルボニル 吸収であるが，詳細は確認してない。

〔後記〕管定剂をいただいた高砂ゴム, 東亚理化, 日東化成, 東京ファインケミカル各社の方々および赤外 吸收判定について打世話になった鉄研の河野通郎，杉山省一の諸氏に感謝いたします。

(1960年 4 月27日 日本ゴム協会研究発表輩演会講演）

文

1) 東业理化：安定剂説明畫の分析法

2) Chemical Appicication of Spectroscopy Interscience (1956) p. 348 その他

3) L. J. Bellamy: The Infrared Spectra of
献

Conplex Molecules (2nd ed.) John Wiley N.Y. (1958) p. 174 6

4）河野通郎，鈴木八十吉，杉山省一：鉄道技術研 究報告 No. 48 (Dec. 1958)

\section{合成高分子の分子量分布に関する研究 ${ }^{* 1}$ \\ （第 3 報） 逐次分別沈澱法による Neoprene WRT と Neoprene GRT の分子量分布について}

\author{
（昭和35年 5 月24日 受理）
}

\section{遠藤 隆 - ${ }^{*}$}

要 旨 Neoprene WRT とGRT のトルエン溶淮から遂次分別沈測法を用いて分別物を作り，乙れら分 別物を作り，てれら分別物のトルエン溶液を $30^{\circ} \mathrm{C}$ で粘度並びに滲透圧を測定した。 その結果より次の粘度 式を得た。
Neoprene GNT
$[\eta]=2.44_{5} \times 10^{-4} \bar{M}_{n}^{0.696}$
Neoprene WRT
$[\eta]=5.07_{4} \times 10^{-4} \bar{M}_{n}^{0.61}$

この埸合の指数 $\alpha$ は GRT の方が WRT より大きく Mochel 等の結果と一致した. Neoprene WRT と GRT の分子量分布曲線を得たが特に GRT の結果は不溶部分を生じたため不充分であつた。

\section{1. 緒言}

高分子物質の分子量分布を測定するととはその物質の成型加工などの方面での基礎的性質を調べるこ とになり重要なことである．特にゴムの場合には加硫の機械的性質に対する効果に大きな影響を及ぼす ものと考えられる。合成ゴムのとのような研究は海外において多く行なわれているが，我が国において

*1 (第 1 報)，(第 2 報) は高分子化学に投稿中

* 東京理科大学化学科 
も合成ゴムの製造が始められた今日，ゴム工業の基礎的研究として我々は Neoprene ゴムを武料とし て逐次分別沈澱法により分別試料を作り，乙れらのトルエン溶液の粘度及び滲透圧を测定し，粘度式を 作ると其にその分子量分布を測定し，若下の知兒を得たので報告する。

\section{2. 実 験 方 法}

\section{1 試料}

試料は Neoprene GRT と Neoprene WRT の2 種存用いた. Neoprene RT 系統は重合の際に 少量のスチレンを共重合させたものといわれ”，普通の Neoprene ゴムはその構造上結晶化し易いの であるが，乙の処理により結晶化の傾问が少ないのが特徴である。Neoprene W は低温で重合させた むのといわれ" Neoprene WRT は Neoprene W と Neoprene RT の特性を共有させたものと考 えられる。

\section{2 溶媒および沈澱剂}

本実験に使用した全部の溶媒，沈飳剂はいづれも常法”を用いで精製したものである。

\section{3 逐次分別沈澱法}

試料 Neoprene $15 \mathrm{~g}$ を $1 l$ のトルエンに加え暗所室温にて溶解させた. この際酸化防止剂として phenyl-- $\beta$-naphthylamine をゴムの重量の $1 \%$ を加えた。ての溶液を G-3 号のガラス沪過器にて清 浄にし, 特別に作った分液沃斗に入れ, $40^{\circ} \mathrm{G} \pm 0.1$ の空気恒温槽中で沈測剂にメタノールを使用して逐 次分別沈澱法にて9区分に分別を行なつた。沈湘の作成はメタノールを少量づつ加えよく摫拌し溶液が 全体に濁るに及びメタノールの滴下を止め, 一度加熱し, 溶液全体を透明にしその後徐冷して $40^{\circ} \mathrm{C} \pm$ 0.1 亿て一昼夜放置し沈港を生成させる．生成した沈測は最初の $1 ， 2$ を除いては透明なゲル状であつ た。この沈澱を下部より取り出し，メタノール洗滌を充分に行ない，溶媒を除去して， $30^{\circ} \mathrm{C}$ の真空乾 燥器で 2 日間にわたり真空乾燥を行ない, 秤量して各区分の重量を決定した。

\section{4 粘 度 測 定}

以上述べたようにして作った分別試料を遥当量採取しトルエンに室温にて溶解させて粘度測定を行な った。この際 2 種類の試料とも最初の分別物（高分子量部）は不溶のゲルとなり測定できなかった。乙 れは乾燥中に架橋し不溶化したものと考えられる。実験に使用した粘度計はウベローデ型の粘度計で粘 度計内で稀勫できるように特別に作ったものである。先に作った溶液（原液）の一定量を採取し，粘度 测定を行ない，後溶媒を加えて稀釈し，粘度を測定するという順にて，嶩度変化を行ない全部で 4 点の 測定を各分別物について行なった。極限粘度の算出は次式により求めた。乙の際運動ユネルギーの補正 を行なった。

$$
\eta_{s} p / C=[\eta]+k^{\prime}[\eta]^{2} C
$$

ここに $C$ は濃度で $\mathrm{g} / 100 \mathrm{cc}$ である。浱度の決定は原液を苲発乾固して行なった。溶液粘度の測定温度 は $30^{\circ} \mathrm{C} \pm 0.001$ の 2 重恒温槽を使用した。

\section{5 浸 透 圧 測 定}

測定に使用した溶液は粘度測定に使用したものを稀釈法を用いて4 個の浱度の違う溶液を作り渗透圧 測定に使用した。滲透压計はZimm-Meyerson 型のもので ${ }^{3)}$ ，半透膜にゲルセロファン（アメリカン ビスコース製) を使用し，水：エタノール（1:1）の系にて一昼夜膨潤させた後"，エタノール100\%， エタノール : アセトン $(1: 1)$, アセトン $100 \%$, アセトン : トルエン (1:1), トルエン 100\%の順に半 日または 1 日の行程にて溶媒置換を行なった後, トルエンにてセルの内外を交換し, 約 1 週間に渡りコ ンディショニングを行なった。滲透圧の測定は低分子量, 低濃度側より行ない, 動的方法》にて実験を 行なった。得た結果より分子量の算出は次の式を用いた。測定に用いた恒温槽は粘度測定に使用したも 
のと同一で $30^{\circ} \mathrm{C} \pm 0.001$ である.

$$
\pi / C=R T / \bar{M}_{n}+A C
$$

\section{3. 実験結果および考察}

\section{1 粘 度 測 定}

各分別物の粘度测定結果を(1) 式に徒ってグラフに目留ると図 1のようになる。乙の図は Neoprene GRT の結果である。同様に Neoprene WRT の結果在図 2 に示す。乙れらより極限粘度〔ク〕を算 出した結果を表 1 に示す。またとの表には先に各試料の禹量を測定した絬果をむ示した。との表より Neoprene GRT では第一，第二分別物が不溶化しその重量分率は30.8\%あり，Neoprene WRT に

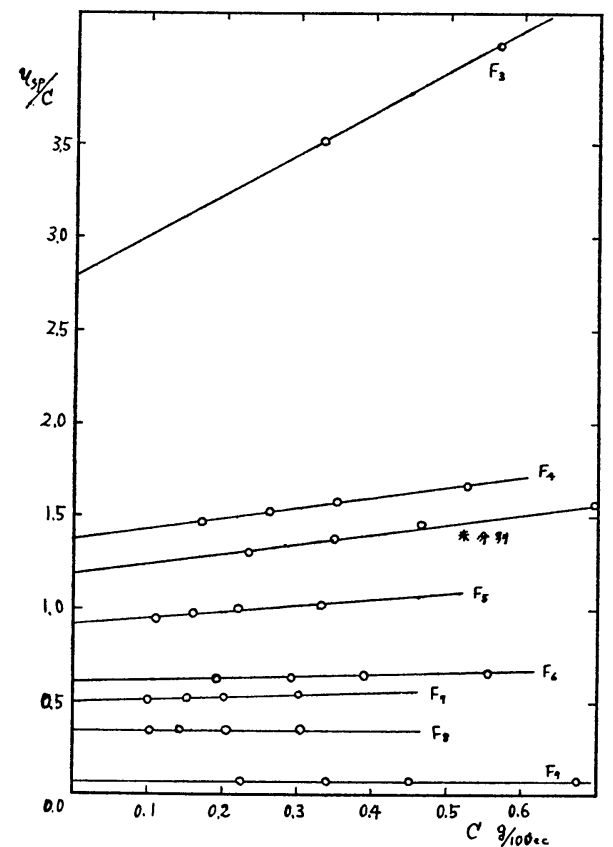

図 1 Neoprene GRT のトルエン浴波の $\eta_{s p} / C$ ¿ の関係 $30^{\circ} \mathrm{C}$

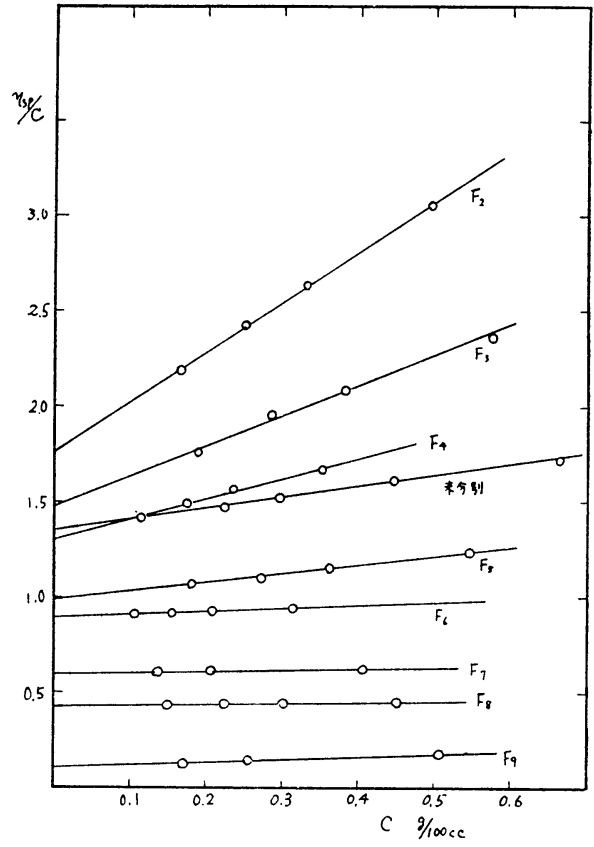

図 2 Neoprene WRT のトルエン浴液の $\eta_{s p} / C$ ¿ の閦係 $30^{\circ} \mathrm{C}$

表 1

\begin{tabular}{|c|c|c|c|c|c|c|c|c|}
\hline \multirow{2}{*}{ 試 料 } & \multicolumn{4}{|c|}{ Neoprene GRT } & \multicolumn{4}{|c|}{ Neoprene WRT } \\
\hline & 沈䬦量 $\mathrm{g}$ & 重量\% & {$[\eta] 100 \mathrm{cc} / \mathrm{g}$} & $\bar{M}_{n} \times 10^{-4}$ & 沈激量 $\mathrm{g}$ & 重量％ & {$[\eta] 100 \mathrm{cc} / \mathrm{g}$} & $\bar{M}_{n} \times 10^{-4}$ \\
\hline $\mathrm{F}_{1}$ & 2.0829 & 16.2 & - & - & 0.4846 & 3.55 & - & - \\
\hline $\mathrm{F}_{2}$ & 1.8743 & 14.6 & - & - & 2.2368 & 16.4 & 1.7600 & 77.82 \\
\hline $\mathrm{F}_{3}$ & 2. 4471 & 19.0 & 2. 7830 & $(69.95)$ & 2.8547 & 20.9 & 1.4711 & $(47.89)$ \\
\hline $\mathrm{F}_{4}$ & 1.8475 & 14.4 & 1.3689 & 18.54 & 0.8117 & $5.9_{5}$ & 1.2984 & $(38.89)$ \\
\hline $\mathrm{F}_{5}$ & 0.6926 & 5.4 & 0.9156 & $(14.16)$ & 3.9258 & 28.8 & 0.9830 & 24.65 \\
\hline $\mathrm{F}_{6}$ & 1.9072 & 14.8 & 0.5996 & $8.46_{8}$ & 0.6478 & 4.8 & 0.8947 & $(21.11)$ \\
\hline $\mathrm{F}_{7}$ & 0.7257 & 5.6 & 0.4894 & $\left(5.75_{0}\right)$ & 1.3145 & 9.6 & 0.5927 & 10.74 \\
\hline $\mathrm{F}_{8}$ & 0.6074 & 4.7 & 0.3460 & 4. $32_{6}$ & 0.5243 & 3.8 & 0.4262 & 6.26 \\
\hline$F_{9}$ & 0.6769 & 5.3 & 0.0686 & $\left(0.34_{1}\right)$ & 0.8441 & 6.2 & 0.0968 & $(0.55)$ \\
\hline 末分別 & - & - & 1.1811 & $9.50_{4}$ & - & - & 1.3563 & 13.35 \\
\hline
\end{tabular}

註（）は粘度式より算出したもの 
おいては第一分別物のみが不溶化しその重量分率は $3.6 \%$ であるととがわかる.

\section{2 浸 透 圧 測 定}

測定結果を(2) 式に従ってグラフに目盛ると, Neoprene GRT については図 3, Neoprene WRT については図 4 亿示す。てれらの結果より(2)式に従って数平均分子量を算出した結果を表 1 に示した。

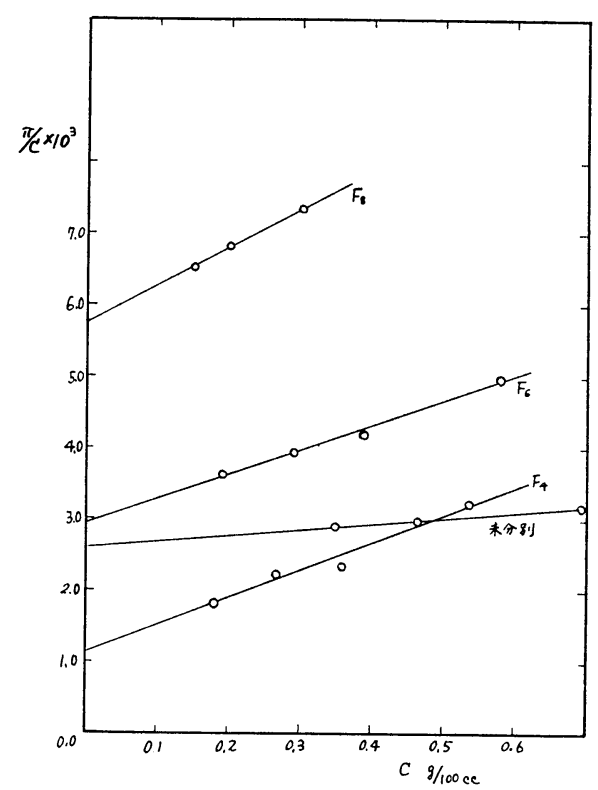

図 3 Neoprene GRT のトルエン溶液の $\pi / C$ と $\mathrm{C}$ の関係 $30^{\circ} \mathrm{C}$

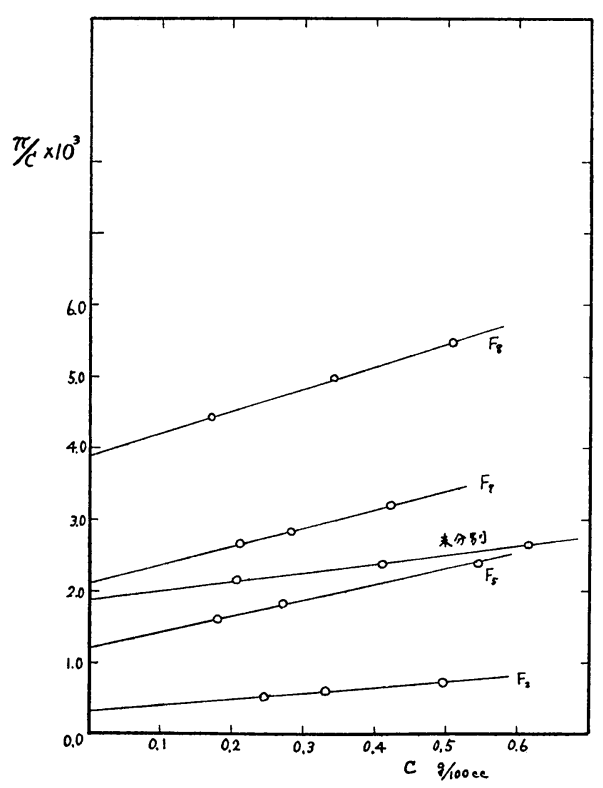

図 4 Neoprene WRT のトルエン溶液の $\pi / C$ \& $\mathrm{G}$ の関係 $30^{\circ} \mathrm{C}$
この分子量の算出に際し溶液の比重は実測值索使 用した。

\section{3 極限粘度と分子量の関係}

このようにして実験した極限粘度と数平均分子 量 $\left(\bar{M}_{n}\right)$ の対数を取り縦軸に極限粘度の対数を, 横軸に分子量の対数を目感ると図 5 の様な結果を 得る。乙の測定結果を最少目乘法を用いて次の粘 度式の恒数 $\mathrm{K}$ と $\alpha$ を計算し, その結果を表 2 に 示す.

$$
[\eta]=K \bar{M}_{n}{ }^{\alpha}
$$

この結果を見ると同じ Neoprene ゴムでもそ の種類により $\alpha$ に若干の差があるととがわかる。 またその值は Neoprene GRT の方が WRTよ り大きいという結果を得た。乙れは重合温度によ り分子構造に若干の差巽を生じ, その結果が粘度 測定に現われたものと思われる。前述のように G-type の方が W-type より $\alpha$ が大きいという

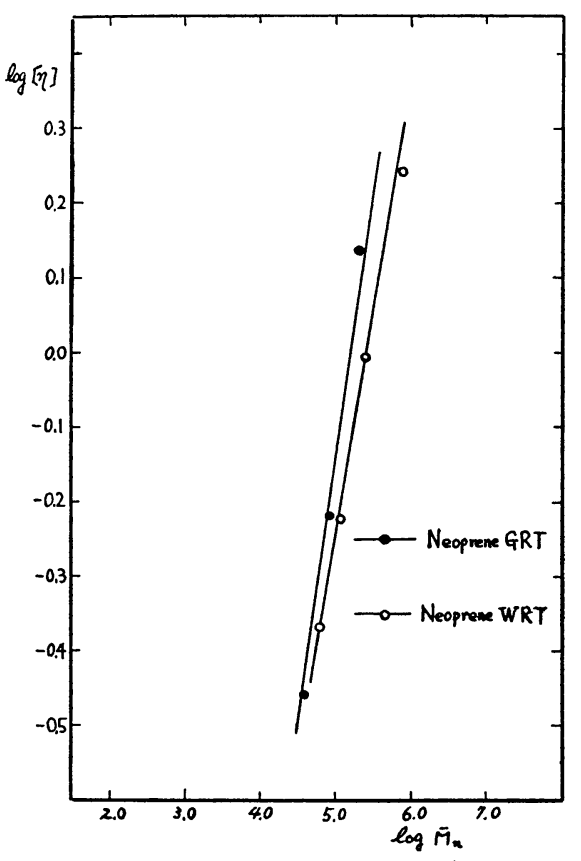

図 5 極限粘度と分子量の関係（トルエン 溶液の $30^{\circ} \mathrm{C}$ の結果) 
表 2

\begin{tabular}{|c|c|c|c|c|c|c|}
\hline 実 験 & \multicolumn{2}{|c|}{ 本実験 } & \multicolumn{4}{|c|}{ 文 献 值 } \\
\hline 試 料 & G R T & WR T & G N A & G N & W & $\mathrm{CG}$ \\
\hline 溶 媒 & トルエン & トルエン & トルエン & ベンゼン & ベンゼン & ベンゼン \\
\hline $\mathrm{K} \times 10^{4}$ & $2.44_{5}$ & $5.07_{4}$ & 5.0 & 1.46 & 1.55 & $0.20_{2}$ \\
\hline$\alpha$ & 0.696 & 0.61 & 0.615 & 0.73 & 0.71 & 0.89 \\
\hline
\end{tabular}

詰 文献值はいづれも $25^{\circ} \mathrm{C}$ の測定結果

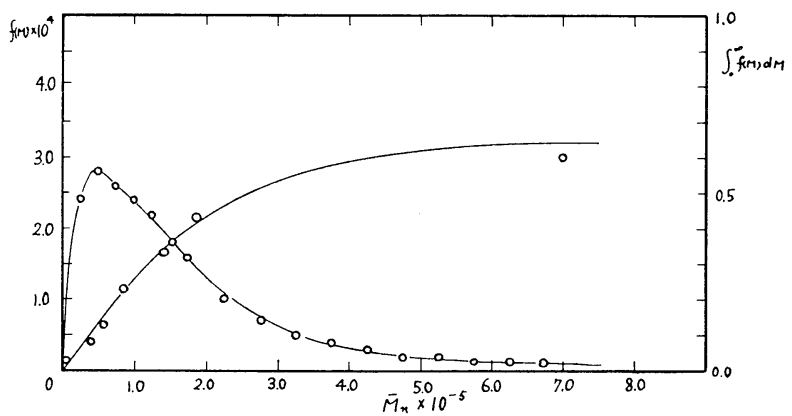

図6 Neoprene GRT の分子量分市

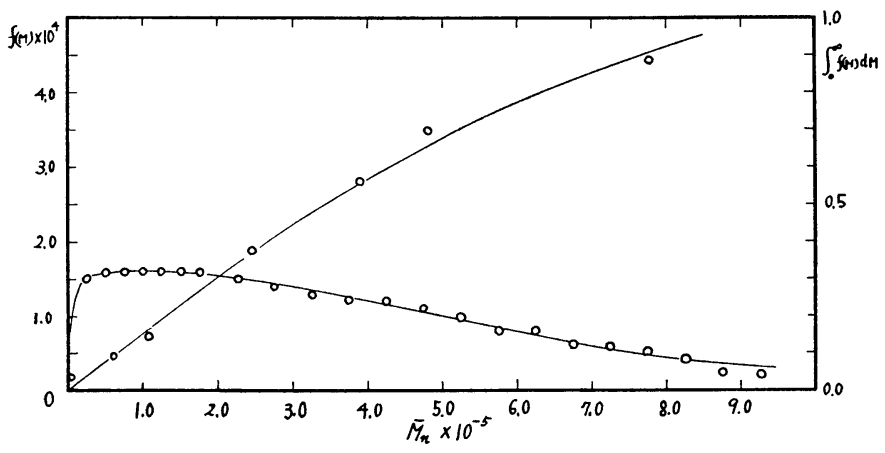

図7 Neoprene WRT の分子量分布

結果は Mochel5，6，7)等によっても われわれと同様の結果が得られてい る. Mochel 等は Neoprene W, $\mathrm{GN}, \mathrm{CG}$ の 3 種の試料について $25^{\circ}$ $\mathrm{C}$ でベンゼン溶液から $\mathrm{K}, \alpha$ を求め ている. この結果によると $\alpha$ の大き さは $\mathrm{GG}>\mathrm{GN}>\mathrm{W}$ の順に小さくな っている. 更 にScott ${ }^{8)}$ 等も Neoprene GNA について $25^{\circ} \mathrm{C}$ でトル エン浴液の奏験より $\mathrm{K}$, と $\alpha$ の值 を求めている。乙れらの絬果を比較 のため表 2 に文献値として示した。

\section{4 分子量分布}

表 1 の重量分率と分子量の関係よ り常法により分子量分布を求めると Neoprene GRT については図6 に, Neoprene WRT については 困7に示した。この結果は GRT については前述のように不溶部分が 30.8\%あり，WRT については3.6 \%不溶部分がある。この数值より見 ると得られた分子量分布はWRTの 方が事実に近い結果を示し， GRT の結果は不充分のように考える。乙 れについては可溶部分について解析 の行なえるスペンサー法を用いて実 験した結果を次報で述べる。なお本 実験によって得た分子量分布は乾燥 中の架橋反必影響走受けているので原試料の分子量分仰に対しては近似的なむのと考える必要がある がこれあ将来検討を行なう予定である。

\section{4. 結 言}

以上の実験結果より次のととが明らかとなった。

(1) Neoprene GRT と WRT の粘度式をトルエン溶液で $30^{\circ} \mathrm{G}$ で測定した絬果

$$
\begin{array}{ll}
\text { Neoprene GRT } & {[\eta]=2.44_{5} \times 10^{-4} \bar{M}_{n}{ }^{0.696}} \\
\text { Neoprene WRT } & {[\eta]=5.07_{4} \times 10^{-4} \bar{M}_{n}^{0.61}}
\end{array}
$$

となり $\alpha$ の大小の関係も Mochel 等と同一傾向であった.

(2) 乙れら試料の分子量分布を求めて分布曲線を得た。しかし Neoprene GRTでは30.8\%,WRT では 3.6\% の不溶部分を生じ充分な結果を得たとは言い難い。この点についてはスペンサー法を用いて 実験しその結果と比較する予定である。 
〔付記】本研究は竹田政民教授御指導の下に行なわれたものであり御指導に感謝致します。また実験に協力 された茂木進君に感謝します。なお本研究の一部は昭和35年 4 月27日, 日本ゴム協会研究発表会に て講演した。

文

1) G.S. Whitby : Synthetic Rubbber

2) 桑田勉 : 溶剂

A. Weissberger et. al : Organic Solvent

3) 飯塚義助: 高化, 11, 425 (1954)

4) 中島章夫 : 滲透圧の測定法

5) W. E. Mochel, J. B. Nichols and C. J. Mighton : J.Am,Chem, Soc., 70, 2185 (1948)
献

6) W. E. Mochel, and J. B. Nichols : J. Am. Chem.Soc., 71, 3435 (1949)

7) W. E. Mochel and J.B. Nichols : Ind. Eng. Chem., 43, 154 (1951)

8) R. L. Scott, W. C. Carter and M. Magat : J. Am.Chem.Soc., 71, 220 (1949)

\title{
合成高分子の分子量分布に関する研究 \\ （第 4 報） スペンサー松本法による Neoprene の分子量 分布について
}

（昭和35年 5 月24日 受理）

\begin{abstract}
遠藤隆
要 旨 Neoprene GRT と Neoprene WRT の 2 種の合成ゴムを試料に用いてトルエンの稀注溶液から スペンサー松本法を使用してそれらのゴムの分子量分布を测定した。

ての方泛は可溶部分を用いての解析により分子量分布が求められるので，前報のように不溶部分を生じる 物愋の分有曲線を求めるには都合が良い。乙の方法で得た結果 Neoprene GRT の分子量分布を前報の結果 と比较すると明膫な差があつたが WRT の絬喿は可成の一致を見た。これらの結染より合成の分子量分布 を知るにはスペンサー松本法は有利な方法と考える。
\end{abstract}

\section{1. 緒言}

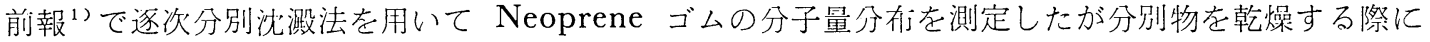
架橋反心が起り不溶部分を生じ，(特に Neoprene GRT) 充分な結果が得られなかった。そこで可溶 部分の粘度測定で分子量分死が得ら机万スペンサー松本法を採用して分子量分们を测定した。乙の方法 は試料溶液に沈澱剂を加え沈測部分と溶液部分とに分けそれぞれの粘度を測定してその結果を解忻して 分布曲線を得るのであるがゴムの塄合には沈澱部分（特に高分子量）が不溶となるので溶液部分の測定 結果より分子量分布曲線を得，乙の絬果と前報との絬果とを比較する。

\section{2. 実 験 方 法}

\section{1 試料}

前報で使用した Neoprene ゴム 2 稆類を試料とした。

\section{2 溶媒および沈澱剂}

前報と同様な方法で精製したものを使用した。

\section{3 分 別 方 法}

スペンサー松本法 ${ }^{2)}$ にる分別方法は試料の桸溥溶液を沛敗部分と溶液部分とに 2 分するのであるが

* 東京理科大学化学科 